\title{
The Implementation of Child-Friendly School in SD Ummul Quro, Semarang Regency
}

\author{
Martien Herna Susanti ${ }^{1, *}$ Maman Rachman ${ }^{2,}$ Anandha $^{3}$ \\ 1,2,3 Department of Politic and Civic, Faculty of Social Sciences, Universitas Negeri Semarang \\ *Corresponding author. Email: martien@mail.unnes.ac.id
}

\begin{abstract}
This study discuss the implementation of Child-friendly School policy, it is a school that guarantee and fulfill children's rights in every aspect of life on a well-planed and responsibly way and also the obstacle on the implementation of Child-friendly School at SD Ummul Quro Semarang Regency. It is a descriptive research design. The research location is at SD Ummul Quro as an Elementary Islamic School that apply holistic curriculum which integrate science-tech, religy, and lifeskill. The results shows that SD Ummul Quro had meet the criteria of childfriendly schools as indicated by the presence of: (1) the declaration as child-friendly school on February 8, 2020, (2) the curriculum implementation, (3) teachers and education personnel that has been trained on children's rights workshop, (4) facilities and infrastructure that support, (5) the child participation, and (6) the parents participation of child-friendly schools implementation. The obstacles of child-friendly school implementations are: (1) there are no mechanism yet for complaints and handling cases of children's rights violations, (2) not all teachers and education personnel have attended training on child rights and child-friendly schools, (3) counseling personnel are not yet available / BP3 (Educational Administering Board) that are well trained, (4) the physical environment of schools that has landslides potency, and (5) there is no participation of community institutions, alumni, and business world in implementing child-friendly school programs.
\end{abstract}

Keywords: Students, Holistic Curriculum, Child-Friendly School.

\section{INTRODUCTION}

This article will describe the implementation of child-friendly schools and the obstacles in implementing child-friendly schools at SD Ummul Quro Semarang Regency. The term child-friendly school was introduced by UNICEF with the term Child-Friendly School(CFS), which is an inclusive, child-centered and gender sensitive school. The school emphasizes teaching effectiveness and community involvement. The CFS model aims to encourage schools and education systems to move progressively towards quality standards to ensure the development of all children[17]. In order to create a conducive atmosphere, several aspects need to be considered are: (1) an appropriate school program; (2) a supportive school environment; and (3) adequate infrastructure aspects. Mpho Modipane and Mahlapahlapana Themane (2014)[10] state that the CFS approach is aimed at making schools function better for the children welfare of children, creating a safe, healthy educational environment, protecting children, and facilitating the realization of education quality.
Regulation of the State Minister for Women's Empowerment and Child Protection of the Republic of Indonesia number 8 of 2014 concerning Child Friendly School Policy, article 1 paragraph (2) and (2) states that a child is someone who is not yet 18 (eighteen) years old, including children who are still in the womb. Children's rights are part of human rights that must be guaranteed, protected, and fulfilled by parents, family, community, government and the state. Tamar Schapiro (1999)[15], defined children over the issue of positive law which stipulate that anyone under the age of seventeen years old are considered as children from the state point of view.

Each child has the right to live, grow, and develop as well as the right to get protection from violence and discrimination "(Article 28B paragraph (2) of the Constitution of the Indonesian Republic Year 1945. Article 9 paragraph (1) of Law Number 23 year 2002 on Child Protection emphasizes that "Every child has the right to get education and teaching on his personal development." Children in and on the school environment must be protected from acts of violence committed by teachers, school administrators or their 
friends in the school or other educational institutions[16].

Regulation of the State Minister for Women's Empowerment and Child Protection of the Republic of Indonesia number 8 of 2014 concerning Child Friendly School Policy, article 1 paragraph (3) states that child-friendly schools are formal, non-formal, and informal education units that are safe, clean and healthy, caring and cultured environment, be able to guarantee, fulfill, respect children's rights, and protect their children from violence, discrimination and other mistreatment and support children's participation, especially in planning, policies, learning, monitoring, and complaint mechanisms related to the fulfillment of children's rights and protection in education.

Indicators of child-friendly schools include six (6) major components, those are: (1) child-friendly schools policy; (2) curriculum implementation; (3) teachers and education personnel trained on children's rights; (4) facilities and infrastructure; (5) children's participation; and (6) parents participation, community institutions, the business world, other stakeholders, and alumni.

King (2019)[8], said that the pedagogical approach that is embedded in the CFS encourages students to have critical thinking and dare to question the knowledge they have learned, so that not only a hierarchical relationship between the traditional teacher and students. Cross (2011)[6], explains that child-friendly school interventions are designed to use all approaches in schools to help build a social competence and student relationships to reduce the possibility of bullying. This program is carefully designed and implemented and engages students in different social contexts. Students are given the right to express their views of science, technology, art, and culture, so that students feel comfortable and happy in the learning process at school[18]. Other than that, the school ensures that every student can enjoy their right to educate without discrimination related to disability, gender, ethnicity, religion, intelligence, and parental background.

Child-friendly schools must create a school situation that is safe, clean and healthy, has concern for culture, the environment, respects rights and protects students from violence, discrimination and ensures student participation in planning, related policies, learning, supervision, and complaint mechanisms to fulfill student rights and protection[7]. The creation of a child-friendly school climate is important based on patterns of experiences of school life, people, and reflects norms, goals, values, interpersonal relationships, teaching and learning practices, and organizational structures (Thapa, Cohen, Guffey, \& Higgins-D'Alessandro , 2013). Bakry's (2010)[2] research shows that education is a public good. Therefore the aspirations of the people at various levels of policy formulation, implementation and evaluation need to be heard and accommodated.

One of the integrated Islamic elementary schools in Semarang Regency that has declared as a child-friendly school is Ummul Quro Elementary School through holistic education, called science-tech, religion, and life skills. This school combines the National Education Curriculum (Department of Education) for the development of (science) for general science, the curriculum of the department of religion for the development of religion and personality / Islamic character, also the local curriculum (local content) for skill development/ vocational character that are Islamic-based.

SD Umm Quro declared as a child-friendly school on February 8, 2020. Unlike the other public elementary schools, the students activity conducted on five (5) working days, those are Monday to Friday starting at $07: 00$ until $15: 15 \mathrm{pm}$ or approximately eight (8) hours. The long time that spent at school makes school as a second home for children that ideally can provide a sense of security and comfort for students to help them in the process of finding their identity and expressing their potency. This condition became a challenge for schools in Indonesia that held full-day learning as explained above.

The survey results show that Indonesia is the second country with the highest bullying cases in the world after Japan, followed by Canada, the United States and Finland[14]. Bullying includes direct behaviors such as teasing, taunting, threatening, hitting, and stealing initiated by one or more students towards a victim and also indirectly causing the victim to be socially isolated (Ahmad \& Smith, 1994; Smith \& Sharp, 1994). The main component of bullying is physical or psychological bullying that occurs repeatedly over time which creates a continuing pattern of abuse (Batsche \& Knoff, 1994; [12]. In a social context, teachers and parents generally do not know the extent of the problem, while other children are reluctant to be involved or do not know how to help (Charach, Pepler, \& Ziegler, 1995). Thus, effective intervention must involve the entire school community, not only the perpetrators and victims. Smith and Sharp (1994) emphasize the need to develop a school-wide bullying policy, implementing the curricular measurements, improve the school environment, and empower students through conflict resolution, peer counseling, and assertiveness training.

In order to make a school that have comfortable condition for the students, and ensure that the schools fulfill the children's rights and protect them, the implementation of child-friendly schools in all education levels are needed, from kindergarten (kindergarten) to high school. Based on description 
above, the research problems are: (1) How is the implementation of child-friendly schools in SD Umul Quro in Semarang Regency?; (2) What are the obstacles in the implementation of child-friendly schools in SD Umul Quro in Semarang Regency .

\section{RESEARCH METHODS}

This study used a qualitative descriptive design[3]. Qualitative research was chosen, because it provides understanding, explanation and theory of social behavior, this type of research can also understand the implementation policy. This approach aim is to obtain comprehensive, systematic, and indepth information from the cases studied[5], those are: (1) implementation of child-friendly schools at SD Ummul Quro at Semarang Regency; and (2) obstacles in the implementation of child-friendly schools in SD Ummul Quro at Semarang Regency. This research took place at SD Ummul Quro Semarang Regency as one of the integrated Islamic elementary schools which declared themselves as a child-friendly school on February 8, 2020. Qualitative research requires focus, because focus relates to context[9]. In this research, context includes place and time, actors or the doer, and also important events that become the research setting. The focus of the study include : (1) child-friendly schools policy; (2) curriculum implementation; (3) teachers and education personnel trained on children's rights; (4) child-friendly school facilities and infrastructure ; (5) children's participation; and (6) participation of parents, community institutions, the business world, other stakeholders, and alumni. The sampling technique that used was purposive sampling and snowball sampling (Sugiyono, 2009). The informants in this study are: teaching staff, education staff, and students. Data collection methods that are compared in this study are the methods of observation, interviews, and documentation. The validity of the collected data was tested using triangulation [1]; Miles and Huberman 1992: 434).

\section{RESULTS AND DISCUSSION}

\subsection{The Implementation of Child-Friendly Schools at SD Ummul Quro Semarang Regency}

Students spent eight hours a day, equivalent with one per three a day required school to prioritize children protection which did by all of school elements started from principals, teachers, counseling teacher, and school guard. Other than that, a good and directed cooperation are needed between schools and parents, community institutions, the business world and alumni to provide a sense of comfort and protection of children's rights in schools through child-friendly schools. Currently, Semarang were succeed to improve its category, from "Kategori Madya" in 2018 into "Kategori Nindya" in 2019 in order to be Children-Worthy Regency (Kota Layak Anak / KLA). Child-friendly school is an indicator of the KLA and the most important part of the publication policy of child-friendly schools to fulfill the children's rights.

There are six indicators to determine how far the child-friendly schools implemented SD Ummul Quro, those are: First, the child-friendly school policy. SD Umm Quro declared as child-friendly school on February 8, 2020. The activities of school learning held in 5 (five) working days starting at 07:00 until $15: 15$ pm, 8 (eight) hours more or less. Every morning the children are accustomed to do Dhuha prayer and memorizing Al'Quran Juz Amma before doing routine learning activities. Other religious activities include the practice of wajib and sunnah prayer reciting correctly, also reading and writing Al-Quran ( Yanbu'a and Qiro'ati). Students break time filled up with worship habituation of congregation Duhur prayer, followed by lunch and a nap. Teaching and learning activities (KBM) were continued again until Ashar. Ashar prayer is a part of learning. The teaching and learning activities were carried out in a pleasant atmosphere, so that children are not burdened with lessons and long hours at school.

Second, the curriculum implementation. Before the declaration of child-friendly schools, SD Ummul Quro has implemented a program of Strengthening the Character Education (Penguatan Pendidikan Karakter/PPK) which integrate good characters in the habituation activities, learning (intra-curricular), cocurricular, and extracurricular activities. The positive impact of the strengthening the character-education program is the strength and sturdy character in schools. Based on the results, teachers support the declaration of child-friendly schools, because their teaching and educating all this time is in accordance with the component of child-friendly schools, so that teachers do not feel awkward and burdened in supporting this program. Child-friendly schools program in line with the school's vision, to produce the ahlaqul karimah learner, intelligent, skillful and competitive. The curriculum used the national curriculum (Curriculum 2013), also uses a local curriculum, called: tahsin, tahfiz Quran, and Arabic language.

Not only teaching and learning activities, the school also organizes various extracurricular activities that the aim is to facilitate and develop students' interests and talents. Extracurricular activities are not carried out outside school hours, but carried out during school hours, every Tuesday and Thursday. Tuesday's extracurricular options are English, Arabic language, qiroah, rebana, mathematics and science, calligraphy, and archery. Thursday's extracurricular choices are dance, vocal rehearsal, drawing and coloring, futsal, and robotics. Students choose freely of two extracurricular provided, but for grade 4 (four) 
and five (5) students, required to follow the scouting activities.

Third, educators and education personnel who were trained in children's rights workshop. Based on interviews, not all teachers get a chance to join the training of child rights and child-friendly schools. Until now, the training has only been attended by principals of SD / MI, SMP / Mts, and SMA / MA who have declared child-friendly schools. One of them was initiated by the Women 's Empowerment and Child Protection Office on a training activity entitled, "Pelatihan Konvensi Hak Anak (KHA) Kota Semarang Tahun 2020" translated into "Training of the Children Rights Convention (KHA) for Semarang Regency in 2020" which was held on 12-13 February 2020.

Four, facilities and infrastructure. This two floors school looks friendly and clean. Students store shoes in a shoe rack at the front of the class, so that the classroom is always clean. To maintain the children comfort, school lockers are provided as private place to store books, prayer equipment, and store the students sleep supplies such as pillows and dolls that were taken from home. There were no dedicated sleeping room yet for nap, and there were only mat that are available for the students to sits. For lunch, the school provides catering and each child has an eating and drinking utensil with their name on it. In order to create a clean and healthy school environment, trash bins that have been differentiated between organic and inorganic waste, also a place for washing hands. Classrooms capacity was in line with the space function, the number of students, and student activity (ratio 1: 30). The classrooms temperature and humidity are comfortable for teaching and learning activities, especially in avoiding glare and reflection of light, noise, and lighting in the classroom were comfortable enough for teaching and learning process. The conditions above are ideal for children to participate in learning activities.

There is a bathroom for boys and girls, which is based on Islamic values and maintains the relationship between men (ikhwan) and women (akhwat). There is also a library, multimedia, and School Health Business (Usaha Kesehatan Sekolah / UKS) near from the teacher's office to make it easier for teacher to supervise if a student is unwell. To support sports activities, the broad school field are available, it also used on the flag ceremony. SD Ummul Quro also equipped with school garden facilities for environmental exploration activities, it also introduce students to the use of empty land around the school.

Fifth, children's participation. Based on the findings, teachers engage students in preparing the classroom rules. According to Sjostrom \& Stein (in Ron Banks, 1997), teachers can work together with students to develop effective classroom rules against bullying in creating a school climate that could rejects violence in schools, including individual intervention with bullies and victims, implementation of learning activities cooperation to reduce social isolation, and increase adult supervision at the crucial times, such as breaks or lunch. Children's participation is also manifested through children's creativity appreciation in the form of classroom decorations, all of which are student's work. Classroom decoration activities are not only carried out by students with the guidance of the class teacher, but also involve the students' parents. It shows appreciation for creativity, innovation, children's creativity, responsibility, independence, and increases self-confidence in children, and also strengthens student communication with parents and also strengthen parents communication with teachers at school.

The sixth is the parents' participation, community institutions, the business community, other stakeholders, and alumni. The implementation of this sixth indicator has not been fully implemented, because it is still limited to parental participation only. This parental participation manifested in a school committee organization and attending school meetings to discuss the school programs. On the activities that involving parents, school managements submit their reports and program policies -Program to be implemented and that has been implemented- either of Semarang Regency Department of Education or from the school and the foundation. Thus, parents have been involved in the preparation of school programs in which they are expected to give support of school programs, especially in implementing the child-friendly schools. Intense communication also intertwined between teachers and parents of students through whatsapp aplication.

The parents active role in school activities are relevant to the statement of Olweus (1993)[12] which states the details of approaches which involving school interventions, classroom and individual levels, including several components: (1) distributing questionnaires to adults and students to understand the extent of the problem, justifies the intervention efforts, also play a role as the measurements to see the impact of school climate improvements after intervention component implemented; (2) raising parental awareness through campaigns in parent-teacher forums, newsletters, and at other gatherings. The aim is to increase parental awareness of the importance of parental involvement and support in the success of the program. Synergy between parents and teachers are absolutely necessary in guiding the students, because at school, teachers nowadays no longer use violent actions to discipline the students in which the possibility of violence could occur in educators' interactions with students, also parents are expected to do the same thing when 
students are at home. SD Ummul Quro has not involved community institutions, the business world, stakeholders, and alumni yet in the child-friendly school program.

\subsection{Obstacles on the Implementation of Child-Friendly School in Sd Ummul Quro Semarang}

School is an institution that has the mandate to organize the process of education and learning in a systematic and continuous way. The teachers and education personnel in schools are expected to provide education and learning that is able to facilitate students to behave in an educated manner which is portray in the form of academic achievement, shows ethical behavior and has noble character, and highly motivated in study. In fact, there was educational process that still takes children as the object and the teacher are 'always right' person so that become potential causes of bullying at schools.

Parents and community that concerns about rampant cases of violence that happened to students at schools, can be minimized through child-friendly schools. Based on the result data, there are several obstacles for SD Ummul Quro in implementing child-friendly school programs. First, there is no mechanism for complaints and handling cases of violations of children's rights, including cases of violence, including sexual crimes, etc. This complaint mechanism is urgently needed, even though there were no such violence cases on this school. The existence of a complaint mechanism and case handling, not only for the indicator of the childfriendly school component, but also makes it easier to measure the effectiveness of the implementation of this child-friendly school. Second, not all teachers and education personnel have participated in child rights training and child-friendly schools training. It makes the implementation of the child-friendly school program was not optimally implemented. Third, there are no trained counseling personnel / BP3 (Education Organizing Board), child rights conventions, child-friendly schools, and students who need special protection (for example: children with disabilities). Due to there are several children with special needs in SD Ummul Quro. Fourth, the school physical environment. Fences that are located next to the cliff with loose soil contours, makes it prone to the landslides. Based on the observations, there was a landslide that caused the school fence collapse. Fifth, there is no participation from community institutions, alumni, and the business world in implementing the child-friendly school program at SD Ummul Quro, considering that the declaration as a child-friendly school has not been carried out for long time and still in the pioneering progress of network building with community institutions, alumni, and the business world on its implementation.

\section{CONCLUSION}

SD Ummul Quro is one of the integrated Islamic elementary schools in Semarang Regency which has declared themselves as a child-friendly school through holistic education, through sciencetech, religious, and life skills. Ideally, school as a second home for children can provide a sense of security and comfort for children to help the process of finding their identity as well as expressing their potential. SD Ummul Quro already meet the 6 (six) component requirements of child-friendly schools, those are: child-friendly schools policy, curriculum, teachers and education personnel that follow the training of child rights, infrastructure, child participation, and the participation of parents in supporting the implementation of the program. The obstacles of implementing child-friendly schools are: First, there are no mechanism for complaints and handling of violations cases of children's rights, including cases of violence, sexual crimes and others. Second, not all educators and education personnel have participated in child rights training and child-friendly schools. Third, there are no trained counseling personnel / BP3 (Educational Administering Board). Fourth, the school physical environment. Fifth, there has not been participation yet of community institutions, alumni, and the business world in implementing child-friendly school programs at SD Ummul Quro.

\section{REFERENCES}

[1] Ahmadi, Rulam.:Metodologi Penelitian Kualitatif. Yogyakarta: Arruzz Media (2016).

[2] Bakry, Amminuddin.: Kebijakan Pendidikan sebagai Kebijakan Publik". Jurnal MEDTEK, Volume 2, Nomor 1, April (2010).

[3] Bungin, Burhan.: Penelitian Kualitatif Edisi Kedua. Jakarta: Prenada Media Grup (2016).

[4] Creswell, John W.: Research Design Pendekatan Kualitatif, Kuantitatif, dan Mixed. Terjemahan Achmad Fawaid. Yogyakarta: Pustaka Pelajar (2010).

[5] Creswell, John W.: Penelitian Kualitatif \& Desain Riset Memilih Diantara Lima Pendekatan Edisi 3. Terjemahan Ahmad Lintang Lazuardi. Yogyakarta: Pustaka Pelajar (2015).

[6] Cross, dkk.: Three-year results of the Friendly Schools whole-of-school intervention on children's bullying behavior. British Educational Research Journal Vol. 37, No. 1, February 2011, pp. 105-129 ISSN 0141-1926 
(print)/ISSN 1469-3518 (online). Routledge Taylor and Francis Group (2011).

[7] Iskandar.: Improving Creativity Teachers Learning, Jakarta: Bestari (2015).

[8] King, Rlizabeth.: Implications for the child friendly schools policy within Cambodia's cultural and primary school context. AsiaPacific Journal of Teacher Education. Routledge Taylor and Francis Group (2019).

[9] Melvy, JM.: Writing The Qualitative Dissertation Understanding by Doing.

[10] Modipane, Mpho \& Mahlapahlapana.: Teachers' social capital as a resource for curriculum development: lessons learnt in the implementation of a Child-Friendly Schools programme. Themane South African Journal of Education, Volume 34, Number 4, November 2014 (2014).

[11] Olweus, D.: Bullying at School Long-Term Outcomes For The Victims And An Effective School-Based Intervention Program. Aggressive Behavior, 97-doi:10.1007/978-14757-9116-7_5 (1978).

[12] Olweus, D.: Bullying at School: What We Know What We Can Do.Cambridge MA: Blackwell Ed (1993).

[13] Peraturan Menteri Negara Pemberdayaan Perempuan dan Perlindungan Anak Republik Indonesia Nomor 8 Tahun 2014 tentang Kebijakan Sekolah Ramah Anak

[14] Pratiwi, Azizun Ajeng.: Retrieved from http://uniqpost.com/50241/negara-negaradengan-kasus-bullying-tertinggi-indonesia-diurutan-ke-2 (2014).

[15] Schapiro, Tamar.:What is Child? Ethics, Vol. 109, No. 4 (July 1999), pp. 715-738.Published by: The University of Chicago Press Stable. URL:

http://www.jstor.org/stable/10.1086/233943 (1999).

[16]Undang-Undang Dasar Negara Republik Indonesia Tahun 1945 Undang-Undang Nomor 23 Tahun 2002 tentang Perlindungan Anak

[17] UNICEF.: UNICEF'S Child-Friendly Schools: Ethiopia Case Study. UNICEF (2010).

[18] Utari, E, Ranti.: Implementation of Child Friendly School Program In SMP Negeri 1 Tempuran Magelang District. Journal of Education Policy Issue 7 Vol. V: 696-707 (2016). 